\title{
BIOTIC SIGNIFICANT CLIMATE TRENDS AND BIOTA DYNAMICS OF THE RUSSIAN ARCTIC
}

Tishkov A. A., Vaisfeld M. A., Glazov P. M., Morozova O. V., Puzachenko A. Yu., Tertytsky G. M., Titova S. V. Institute of Geography, Russian Academy of Sciences (Moscow, Russian Federation)

The article was received on December 19, 2018

\begin{abstract}
The article shows specific examples of the current dynamics of the Arctic biota, due to biotic significant climate changes or other factors that are important for understanding modern processes in the ecosystems of the Russian Arctic. The formation paths of current habitats of Arctic mammals are traced and a forecast of their changes is given with further climate warming, features of the population dynamics in recent decades for model species of waterfowl (Barnacle Goose) and seafowl (Herring Gull) are revealed. It is shown that not all changes in the Arctic biota can be explained by climate changes. The analysis is supplemented with materials assessing the current dynamics of the Arctic flora and vegetation. A mechanism of the Arctic "greening" is shown in terms of the assessment using remote sensing methods for the development of tree-shrub vegetation in certain territories of the Murmansk region.
\end{abstract}

Keywords: Russian Arctic, Arctic biota, remote sensing, the tundra "greening", area, population dynamics, migration, mammals, birds, flora, vegetation

The work was carried out under the Russian Foundation for Basic Research grant 18-05-60057 "The tundra "greening" of as a driver of the Arctic biota modern dynamics" and within the framework of the state assignment no. 0148-2019-0007 of the Institute of Geography of the Russian Academy of Sciences.

\section{Information about the authors}

Tishkov Arkadiy Alexandrovich, Doctor of Geographic Sciences, Corresponding Member of RAS, Professor, Deputy Director, Institute of Geography, RAS (29, Staromonetny per., Moscow, Russia, 119017), e-mail: tishkov@ biodat.ru.

Vaisfeld Mikhail Arnoldovich, PhD of Geographic Sciences, Leading Researcher, Institute of Geography, RAS (29, Staromonetny per., Moscow, Russia, 119017), e-mail: mvisfeld@mail.ru.

Glazov Peter Mikhailovich, Researcher, Institute of Geography, RAS (29, Staromonetny per., Moscow, Russia, 119017), e-mail: glazpech@mail.ru.

Morozova Olga Vasil'evna, PhD of Geographic Sciences, Leading Researcher , Institute of Geography, RAS (29, Staromonetny per., Moscow, Russia, 119017), e-mail: olga.morozova@igras.ru.

Puzachenko Andrey Yur'evich, Doctor of Biological Sciences, Leading Researcher, Institute of Geography, RAS (29, Staromonetny per., Moscow, Russia, 119017), e-mail: puzak@igras.ru.

Tertitsky Grigory Markovich, Senior Researcher, Institute of Geography, RAS (29, Staromonetny per., Moscow, Russia, 119017), e-mail: tertitski@mail.ru.

Titova Svetlana Vladimirovna, Researcher, Institute of Geography, RAS (29, Staromonetny per., Moscow, Russia, 119017), e-mail: canopuss@yandex.ru.

\section{Bibliographic description}

Tishkov A. A., Vaisfeld M. A., Glazov P. M., Morozova O. V., Puzachenko A. Yu., Tertytsky G. M., Titova S. V. Biotic significant climate trends and biota dynamics of the Russian Arctic. Arctic: Ecology and Economy, 2019, no. 1 (33), pp. 71-87. DOI: 10.25283/2223-4594-2019-1-71-87. (In Russian). 


\section{References}

1. Kokorin A. O. Izmenenie klimata: obzor Pyatogo otsenochnogo doklada MGEIK. [Climate changes: review of $5^{\text {th }}$ assessment report of IPCC]. Moscow, Vsemir. fond dikoi prirody (WWF), 2014, 80 p. (In Russian).

2. Vtoroi otsenochnyi doklad Rosgidrometa ob izmeneniyakh klimata i ikh posledstviyakh na territorii Rossiiskoi Federatsii: Tekhnicheskoe rezyume. [2nd assessment report of Roshydromet on climate change and its consequences on the territory of the Russian Federation]. Moscow, Rosgidromet, 2014, 94 p. (In Russian).

3. Serebryanny L. R., Tishkov A. A., Malyasova Je. S., Solomina O. N., Il'ves E. O. Reconstruction of the development of vegetation in Arctic high latitudes. Polar Geography and Geology, 1985, vol. 9, no. 4, pp. 308-320. 4. Tishkov A. A. Ekosistemy zapadnogo poberezh'ya Shpitsbergena (arkhipelag Sval'bard). [The ecosystems of western coast of Spitsbergen (Svalbard)]. Izv. AN SSSR. Ser. geogr., 1983, no. 6, pp. 99-109. (In Russian).

5. Tishkov A. A., Krenke-ml. A. N. "Pozelenenie" Arktiki v XXI v. kak effekt sinergizma deistviya global'nogo potepleniya i khozyaistvennogo osvoeniya. ["Greening" of the Arctic in the XXI century as a synergy effect of global warming and economic development]. Arktika: ekologiya i ekonomika, 2015, no. 4 (20), pp. 28-37. (In Russian).

6. Belonovskaya E. A., Tishkov A. A., Vaisfel'd M. A., Glazov P. M., Krenke-ml. A. N., Morozova O. V., Pokrovskaya I. V., Tsarevskaya N. G., Tertitskii G. M. "Pozelenenie" rossiiskoi Arktiki i sovremennye trendy izmeneniya ee bioty. ["Greening" of the Russian Arctic and the Modern Trends of Transformation of Its Biota]. Izvestiya RAN. Ser. geogr., 2016, no. 3, pp. 28-39. DOI: 10.15356/0373-2444-2016-3-28-39. (In Russian).

7. Tishkov A. A., Belonovskaya E. A., Vaisfel'd M. A., Glazov P. M., Krenke A. N., Tertitskii G. M. «Pozelenenie» tundry kak draiver sovremennoi dinamiki arkticheskoi bioty. ["The greening" of the tundra as a driver of the modern ,dynamics of arctic biota ]. Arktika: ekologiya i ekonomika, 2018, no. 2 (30), pp. 31-44. DOI: 10.25283/2223-4594-2018-2-31-44. (In Russian).

8. Markova A. K., van Kol'fskhoten T., Bokhnkke Sh., Kosintsev P. A., Mol I., Puzachenko A. Yu., Simakova A. N., Smirnov N. G., Verpoorte A., Golovachev I. B. Evolyutsiya ekosistem Evropy pri perekhode ot pleistotsena k golotsenu (24-8 tys. I. n.). [Evolution of ecosystems in Europe in the transition from the Pleistocene to the Holocene (24-8 thousand]. Moscow, Izd-vo KMK, 2008, 556 p. (In Russian).

9. Olson D. M., Dinerstein E., Wikramanayake E. D. et al. Terrestrial ecoregions of the World: A New Map of Life on Earth. Bioscience, 2001. vol. 51, no. 11, pp. 933-938.

10. Uspenskii S. M. Nekotorye vidy ptits na severovostoke evropeiskoi chasti SSSR. [Some bird species in the North-East of the European part of the USSR]. Uch. zap. Mosk. un-ta, 1958, no. 197, pp. 35-47. (In Russian).
11. Krasnaya kniga SSSR: Redkie i nakhodyashchiesya pod ugrozoi ischeznoveniya vidy zhivotnykh i rastenii. [Red book of the USSR: rare and endangered species of animals and plants]. Vol. 1. 2nd ed. Moscow, Lesnaya prom-st', 1984, 392 p. (In Russian).

12. Kalyakin V. N. Novye dannye po faune ptits Novoi Zemli i Zemli Frantsa-losifa. [New data on birds fauna of Novaya Zemlya and Franz-Josef Lands]. Ornitologiya, 2001, no. 29. pp. 8-28. (In Russian).

13. Morozov V. V. Materialy k poznaniyu fauny ptits ostrova Vaigach. [The matrials to study of fauna of Vaigach island]. Ornitologiya, 2001, no. 29, pp. 29-46. (In Russian).

14. Kalyakin V. N. O rasprostranenii i ekologii beloshchekoi kazarki na o-ve Vaigach i Yugorskom poluostrove. [About distribution and ecology of Bernicle goose in Vaigach island and Yugorsky peninsula]. Aktual'nye problemy ornitologii. Moscow, Nauka, 1986, pp. 93-104. (In Russian).

15. Syroechkovsky E. V., Litvin K. E., Ebbinge B. S. Breeding success of geese and swans on Vaygach Island (USSR) during 1986-1988; interplay of weather and Arctic Fox predation. Ardea, 1991, vol. 79 (3), pp. 373-382.

16. Ponomareva T. S. Beloshchekaya kazarka. Novoe gnezdovoe poselenie $v$ okrestnostyakh o. Kolgueva. [Barnacle goose: a new nesting behaviour in the vicinity of Kolguyev island]. Itogi izucheniya redkikh zhivotnykh (Materialy k Krasnoi knige). Moscow, TsNIIL Glavokhoty RSFSR, 1990, pp. 81-84. (In Russian).

17. Ganter B., Larsson K., Syroechkovsky E. V., Litvin K. E., Leito A., Madsen J. Barnacle Goose Branta leucopsis: Russia/Baltic. Goose populations of the Western Palearctic. A Review of Status and Distribution. J. Madsen, G. Cracknell, T. Fox (eds.). Wageningen, 1999, pp. 270-283.

18. Fox A. D., Madsen J. Threatened species to super-abundance: The unexpected international implications of successful goose conservation. Ambio, 2017, vol. 46 (Suppl. 2), pp. 179-187. DOI 10.1007/ s13280-016-0878-2.

19. Bianki V. V. Kuliki, chaiki i chistikovye Kandalakshskogo zaliva. [Waders, gulls, auks of Kandalaksha Bay]. Tr. Kandalaksh. gos. zapovednika, 1967, iss. 6, 365 p. (In Russian).

20. Khitun O. V., Koroleva T. M., Chinenko S. V., Petrovsky V. S., Pospelova E. B., Pospelov I. N., Zverev A. Applications of local floras for floristic subdivision and monitoring vascular plant diversity in the Russian Arctic. Arctic Science, 2016, vol. 2, pp. 103-126. DOI: 10.1139/AS-2015-0010.

21. Myers-Smith I., Forbes B. C., Wilmking M., Hallinger M., Lantz T., Blok D., Tape K. D., Macias-Fauria M., SassKlaassen $U$. et al. Shrub expansion in tundra ecosystems: dynamics, impacts and research priorities. Environ. Res. Lett., 2011 , vol. 6 (4). 045509.

22. Elmendorf S. C., Henry G. H. R., Hollister R. D., Björk R. G., Bjorkman A. D., Callaghan T. V. et al. Global assessment of experimental climate warming on tundra 
vegetation: heterogeneity over space and time. Ecology Letters, 2012, vol. 15 (2), pp. 164-175. DOI: 10.1111/j.1461-0248.2011.01716.x.

23. Walker D. A., Epstein H. E., Raynolds M. K., Kuss P., Kopecky M. A., Frost G. V., Daniëls F. J. A., Leibman M. O., Moskalenko N. G., Matyshak G. V., Khitun O. V., Khomutov A. V., Forbes B. C., Bhatt U. S., Kade A. N., Vonlanthen C. M., Tichy L. Environment, vegetation and greenness (NDVI) along the North America and Eurasia Arctic transects. Environ. Res. Lett., 2012, vol. 7 (1). 015504. DOI: 10.1088/1748-9326/7/1/015504.

24. Callaghan T. V., Jonasson C., Thierfelder T., Yang Z., Hedenas H., Johansson M., Sloan V. L. Ecosystem change and stability over multiple decades in the Swedish subarctic: complex processes and multiple drivers. Philosophical Transactions of the Royal Society B. Biological Sciences, 2013, vol. 368 (1624). DOI: 10.1098/ rstb.2012.0488.

25. Pospelova E. B., Pospelov I. N. Izmeneniya vo flore okrestnostei s. Khatanga, Taimyrskii zapovednik, za dlitel'nyi period. [The changes in the flora of the surroundings of Khatanga village, Taimyr reserve, over a long period]. Zapoved. nauka, 2016, vol. 1 (2), pp. 59-78. (In Russian).

26. Pospelova E. B., Pospelov I. N., Orlov M. V. Vozdeistvie klimaticheskikh kolebanii na vostoke Taimyra za 80-letnii period na rastitel'nyi i zhivotnyi mir ego territorii. [The impact of climatic fluctuations in the East of Taimyr for 80 years on the flora and fauna of its territories]. Nauch. tr. Feder. gos. byudzhet. uchrezhdeniya Ob"edinennaya direktsiya zapovednikov Taimyra. Vol. 2. Apeks, Noril'sk, 2018, pp. 127-141. (In Russian).

27. Lavrinenko I. A., Lavrinenko O. V. Vliyanie klimaticheskikh izmenenii na rastitel'nyi pokrov ostrovov Barentseva morya. [The influence of climate changes on vegetation cover of Barents see islands]. Tr. Karel. nauch. tsentra, 2013, no. 6, pp. 4-16. (In Russian).

28. Matveeva N. V., Zanokha L. L., Yanchenko Z. A. Izmeneniya vo flore sosudistykh rastenii $v$ raione Taimyrskogo biogeotsenologicheskogo statsionara (srednee techenie reki Pyasiny, Zapadnyi Taimyr) s 1970 po $2010 \mathrm{~g}$. [Changes in the flora of vascular plants in the vicinity of the Taimyr biogeocenological station (middle reaches of the river Pyasina river, Western Taymyr) from 1970 to 2010]. Botan. zhurn., 2014, vol. 99, no. 8, pp. 841-867. (In Russian).

29. Pospelova E. V., Pospelov I. N., Orlov M. V. Climate change in Eastern Taimyr over the last 80 years and warming impact on biodiversity and ecosystem processes in its territory. Nature Conservation Research, 2017, vol. 2 (3), pp. 48-60. DOI: 10.24189/ ncr.2017.040. 
DOI: $\mathbf{1 0 . 2 5 2 8 3 / 2 2 2 3 - 4 5 9 4 - 2 0 1 9 - 1 - 7 1 - 8 7}$

УДК 502.31: 504.05 (551.5)

\title{
БИОТИЧЕСКИ ЗНАЧИМЫЕ ТРЕНДЫ КЛИМАТА И ДИНАМИКА БИОТЫ РОССИЙСКОЙ АРКТИКИ
}

\author{
А. А. Тишков, М. А. Вайсфельд, П. М. Глазов, О. В. Морозова, А. Ю. Пузаченко, \\ Г. М. Тертицкий, С. В. Титова \\ ФГБУН Институт географии РАН (Москва, Российская Федерация)
}

Статья поступила в редакцию 19 декабря 2018 г.

На конкретных примерах показаны особенности современной динамики арктической биоты, обусловленные биотически значимыми изменениями климата или другими причинами, которые важны для понимания современных процессов в экосистемах российской Арктики. Прослежены пути формирования современных ареалов арктических млекопитающих и дан прогноз их изменений при дальнейшем потеплении климата, выявлены особенности динамики численности в последние десятилетия модельных видов водоплавающих (белощекой казарки) и морских (серебристой чайки) птии. Показано, что не все изменения арктической биоты можно объяснить изменениями климата. Анализ дополнен материалами по оценке современной динамики арктических флоры и растительности. На примере оценки с помощью дистанционных методов развития древесно-кустарниковой растительности отдельных территорий Мурманской области показан один из механизмов «позеленения» Арктики.

Ключевые слова: росийская Арктика, арктическая биота, дистанционное зондирование, «позеленение» тундры, ареал, динамика численности, миграции, млекопитающие, птищы, флора, растительность.

\section{Введение \\ По данным Пятого оценочного доклада Межпра- вительственной группы экспертов по изменению климата (МГЭИК) 2014 г. [1], включавшего на этот раз специальный раздел «Воздействие на природу и человека», и Второго оценочного доклада Росгид- ромета по изменению климата [2], в российской Арк- тике сохраняется ряд биотически значимых трендов как реакция на так называемые наблюдаемые из- менения климата, хотя, как видно по публикуемым картам, север Евразии в XXI в. испытывает разные по интенсивности и направленности изменения кли- матических параметров: \\ - сохраняется рост концентрации диоксида угле- рода в приземных слоях атмосферы: в 2013 г. - $392,5 \mathrm{млн}^{-1}$, а в 2017 г. - 403,55 млн ${ }^{-1}$;}

(ㄷ Тишков А. А., Вайсфельд М. А., Глазов П. М., Морозова О. В., Пузаченко А. Ю., Тертицкий Г. М., Титова С. В., 2019
- продолжается рост годовой температуры, коэффициент линейного тренда - до 0,7-0,9 ${ }^{\circ} \mathrm{C} / 10$ лет, в основном на полуострове Таймыр, в Якутии и на арктических архипелагах; теплее и продолжительнее лето и осень в азиатской части российской Арктики, зима холоднее на северо-востоке Сибири $\left(-1{ }^{\circ} \mathrm{C} / 10\right.$ лет);

- контрастные по вектору тренды наблюдаются в отношении осадков; положительный тренд на Кольском полуострове и в Большеземельской тундре (до +100 мм в год), снижение - на полуостровах Ямал и Таймыр (до -50 мм в год); количество снега и высота его покрова растут в европейской России (6-10 см/10 лет), сокращение сроков снежного покрова - на 4-8 сут/10 лет;

- если на всей территории России скорость приземного ветра падает, то в Арктике, особенно на архипелагах и севере полуострова Таймыр, в последние десятилетия скорость ветра растет с линейным трендом 0,5 м/с/10 лет. 
Суммируя, определим, что в российской Арктике начиная с 1990-х годов сохраняется тренд потепления: мягче стали зимы, выросла продолжительность вегетационного периода, обновляются абсолютные рекорды температур (в основном положительных), происходит рост количества осадков, в том числе снега, в ряде мест растет мощность снежного покрова, повсеместно - скорость приземного ветра, в акватории Северного Ледовитого океана сократились площадь многолетних льдов и их мощность (почти на 40\%), над побережьем и архипелагами стали преобладать антициклонические процессы в атмосфере. Практически все эти выявляемые тренды можно отнести к «биотически значимым», т. е. они прямо или опосредованно могут существенно повлиять на распространение, развитие, воспроизводство, динамику численности и характер миграций арктической биоты. Важно понять, как такая перестройка климата в Арктике повлияет на будущий ее статус и состояние биоты, какие изменения биоты будут необратимыми, а какие в процессе циклических изменений «вернутся» на конвергентные к исходным позиции.

Опираясь на заключения климатологов [1; 2], можно определить, что в ряду циклических изменений климата - тысячелетних, вековых и внутривековых - современный период демонстрирует аномально высокие темпы потепления, которые способны вызвать коренные (в том числе и необратимые) перестройки биоты как на материковой полосе тундр, так и на архипелагах Арктики. В обоих случаях эффект «быстрых» изменений климата может быть один - полная трансформация экосистем, вымирание арктической биоты, замещение ее более теплолюбивыми биотическими комплексами, редуцированными и не очень жизнестойкими. Известно, что Арктика многократно в прошлом становилась местом, где климатические аномалии приводили на значительный период (десятилетия и столетия) к коренным изменениям биоты и экосистем: лесная растительность вытесняла тундры вплоть до побережья Северного Ледовитого океана [3], вымирали сформировавшиеся в теплый период островные популяции дикого северного оленя [4], происходило активное освоение птицами архипелагов, расширялись, а потом исчезали крупные птичьи базары. До сих пор в российской Арктике находят пни деревьев в сотнях километрах севернее современной границы, а споро-пыльцевые спектры торфов арктического побережья отражают лесотундровые условия [3].

Что показывают прогнозные карты и современные модели в отношении будущих изменений климата российской Арктики? В период подготовки Пятого оценочного доклада МГЭИК (2008-2014 гг.), как известно, анализировался ансамбль модельных расчетов по климату - Проект взаимосравнения объединенных моделей поведения атмосферы и океана (5-я фаза) (CMIP5) [1]. Всего использовалось более
50 моделей. В итоге прогнозируется, что наибольшие сдвиги в сторону потепления на Земле будут в ближайшее столетие характерны для высокой Арктики (район Земли Франца-Иосифа, Северного острова Новой Земли, Северной Земли и др.) - рост сезонной температуры на $6-8^{\circ} \mathrm{C}$ к 2099 г. и рост зимних температур до $10-12^{\circ} \mathrm{C}$. Повсеместно ожидается рост количества осадков. По оценке ансамбля из 31 модели CMIP5 российская Арктика к серединеконцу XXI в. станет ареной наиболее сильных сдвигов биотически значимых параметров климата [2].

Настоявшая статья посвящена выявлению на отдельных примерах закономерностей современной динамики арктической биоты для понимания направленности ее будущих изменений, связанных с изменениями климата.

\section{Материалы и методы}

Для анализа и синтеза данных по изменчивости арктической биоты российской Арктики использовались материалы собственных полевых исследований и литературные данные, собранные по гранту РФФИ "“Позеленение” тундры как драйвер современной динамики арктической биоты» № 18-05-60057, в том числе ранее частично опубликованные [5-7]. Для реконструкции прошлых ареалов арктических млекопитающих, выявления особенностей формирования их современных ареалов, для оценки возможных климатогенных и антропогенных изменений флоры российской Арктики, в том числе инвазий чужеродных видов, использовались зарегистрированные в Роспатенте базы данных лаборатории биогеографии Института географии РAH: (а) PALEOFAUNA (номер государственной регистрации 2011620493), (г) цифровых ареалов наземных позвоночных северной Евразии (№ 2016621524), (д) оценки биогеографических последствий инвазий чужеродных видов растений восточной Европы (№ 2011620495$)$ - БД AliS, которая на конец 2018 г. содержала сведения о 2034 видах и числе находок 23 112. В процессе полевых исследований арктических птиц, проводимых на островах Белого моря, в низовьях Печоры, на острове Колгуев, на Кольском полуострове и др., использовались стандартные методы учета численности птиц на гнездовьях, в колониях и местах их концентрации. Проведены отловы и кольцевание гусеобразных птиц (белолобых гусей, гуменников, белощеких казарок и др.) на острове Колгуев. Для изучения миграций четыре гуменника были помечены GPS-GSM передатчиками.

При подготовке статьи применялись методы цифровой картографии и ГИС-технологии, позволяющие проводить картографический анализ и синтез данных по распространению и миграциям животных. Для оценки процессов «позеленения» тундр (роста продуктивности) арктических регионов был проведен сравнительный анализ данных снимков среднего разрешения серии Landsat 2000 и 2010 гг. на Кольском полуострове. Данные представляли собой 


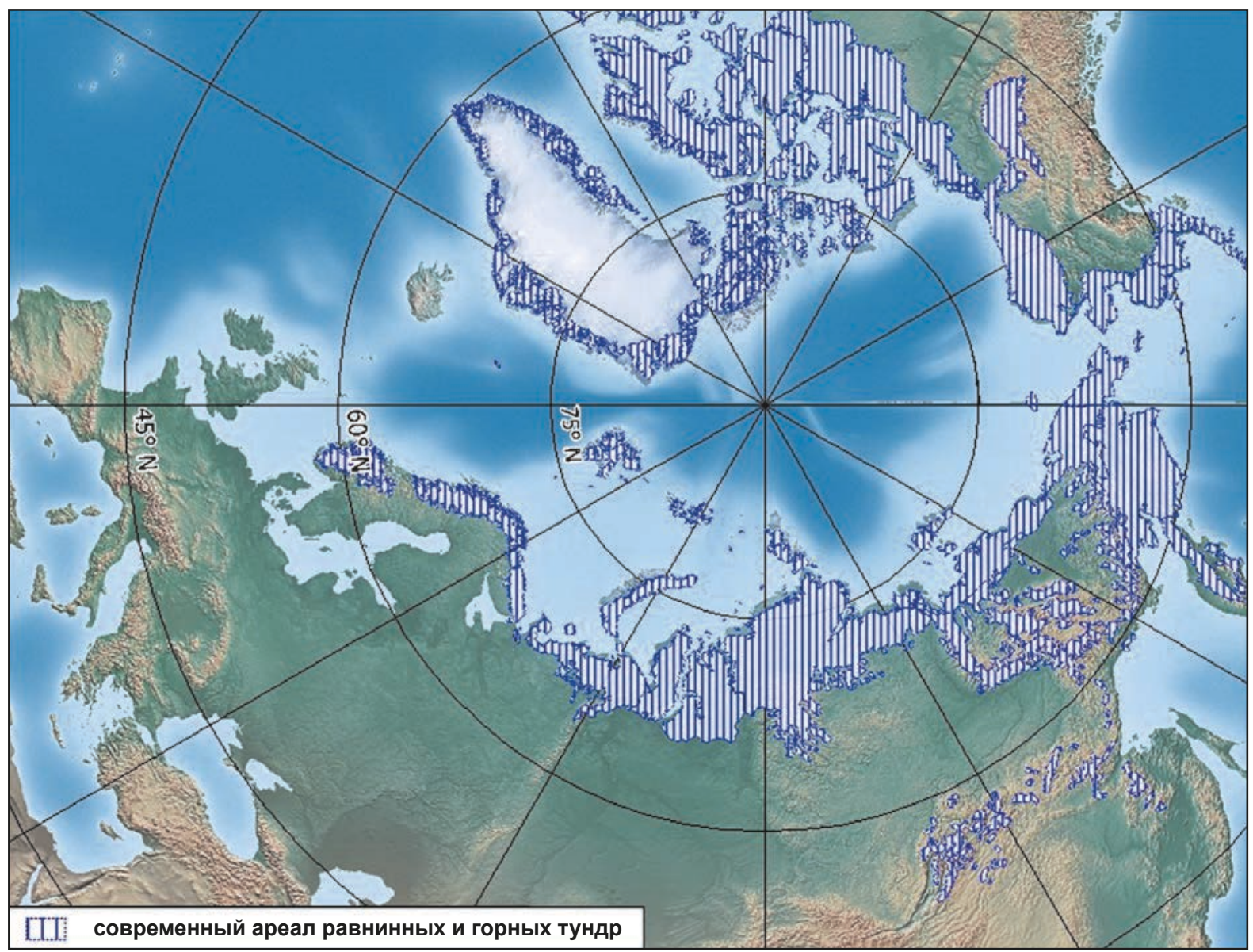

Рис. 1. Современный ареал биома арктических и оро-арктических тундр [9]

Fig. 1. The modern habitat of the Arctic and Oro-Arctic tundra biome [9]

растр разрешением 30×30 м и со значением покрытой лесом и кустарниками площади в процентах для каждого пикселя.

\section{Результаты и их обсуждение}

Особенности формирования современных ареалов арктических млекопитающих. Современные ареалы большинства арктических видов млекопитающих Евразии ограничены тундрой в основном в азиатской части материка, простирающейся вдоль побережья арктических морей. В представлении западных коллег арктический биом включает и горно-альпийские территории северо-востока азиатской части России (рис. 1). Анализ палеонтологического материала показывает, что в период максимума последнего оледенения южные границы их ареалов были расположены южнее и охватывали большую часть европейского субконтинента. Это важно учитывать не только для палеоэкологических реконструкций [8], но и при прогнозе климатогенных перестроек распространения арктической биоты.

Деградация плейстоценовых ареалов холодолюбивых видов происходила постепенно в интервале от 20 до примерно 4 тыс. лет и под влиянием разных сочетаний экологических факторов. Формирование «современных» ареалов млекопитающих арктических тундр произошло на границе среднего и позднего голоцена. Характер процесса определялся биологическими особенностями видов. Ниже представлены изменения ареалов трех видов млекопитающих, иллюстрирующие данное положение. История формирования ареалов позволяет дать прогноз их изменений при долговременном тренде климата российской Арктики в XXI в. [8].

Овцебык (Ovibos moschatus) - типичный холодолюбивый вид травоядных млекопитающих, характерный представитель фауны плейстоцена Евразии и Северной Америки, характеризуется набором адаптаций к суровых условиям климата и скудной кормовой базе. На максимальной стадии оледенения 28,85-20,25 тыс. лет назад (здесь и далее - календарные датировки) его ареал охватывал широкую полосу от Пиреней на юго-западе до юга Сибири и простирался до северо-востока Азии (Беренгия), где соединялся с участком ареала в Северной Америке, свободным от Лаврентийского ледникового щита (рис. 2). В послеледниковье по мере потепления ареал сокращался, распадаясь на отдельные изолированные популяции. Резкое потепление на рубеже плейстоцена и голоцена (пример- 

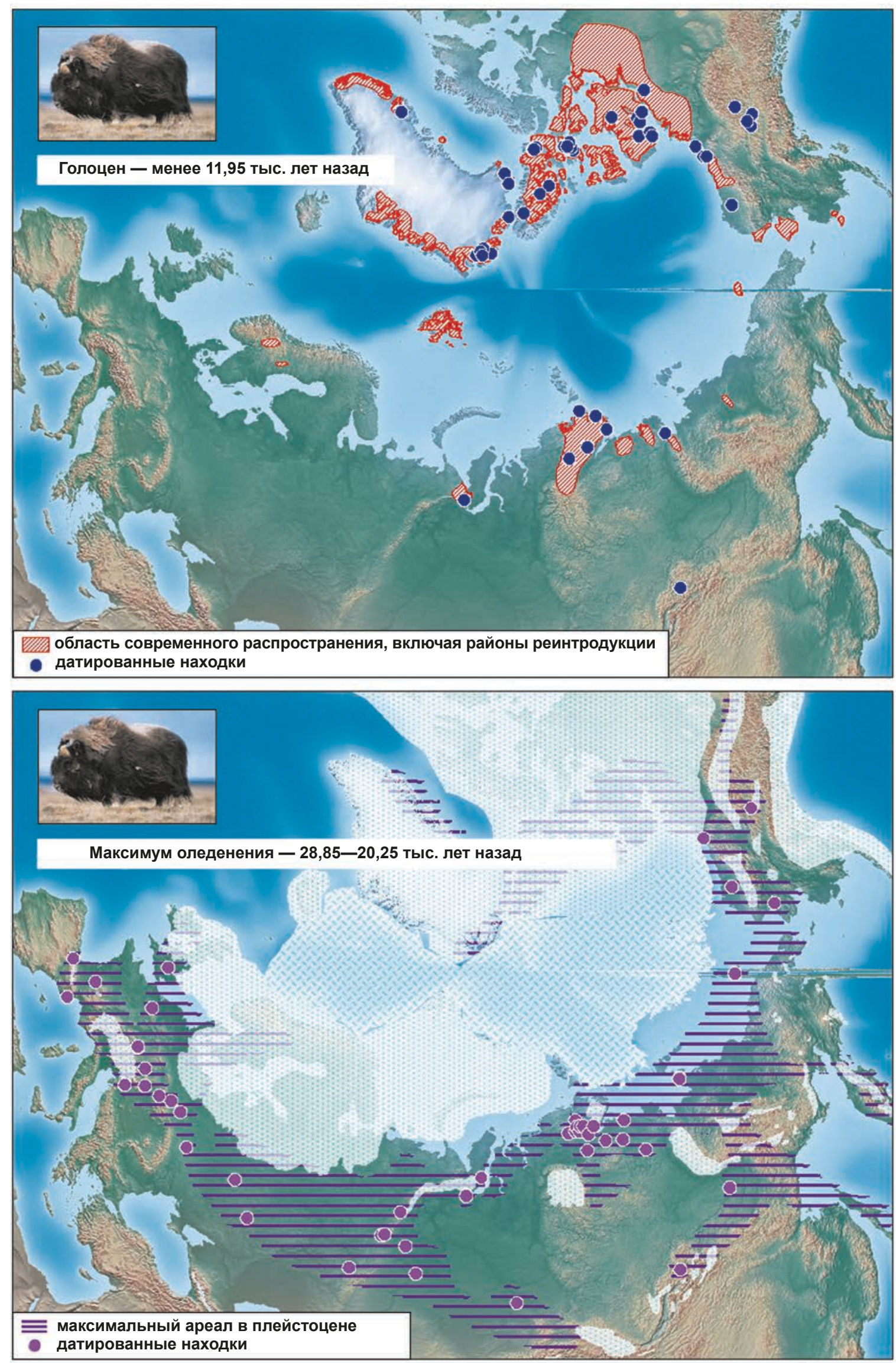

Рис. 2. Ареал овцебыка в плейстоцене и голоцене

Fig. 2. Musk Ox distribution in the Pleistocene and Holocene 
но 11,95 тыс. лет назад) привело к окончательному вымиранию вида на большей части ареала в Евразии. При этом отдельные изолированные популяции вида существовали в Азии: изолированные популяции просуществовали на Полярном Урале, полуострове Таймыр и в районе дельты Лены в интервале 6,3-2,7 тыс. лет назад (суббореал). $K$ началу субатлантики вид полностью вымер в Евразии, но сохранился в Северной Америке и Гренландии. В XX в. была проведена успешная реинтродукция овцебыка на территории последних голоценовых евразийских рефугиумов, что показало приемлемость современного климата арктических тундр для вида.

Вероятными критическими факторами для овцебыков являются высота снежного покрова зимой и летние температуры. Высокий снежный покров препятствует добыче корма, а высокие летние температуры приводят к нарушению терморегуляции. Биотически значимыми изменениями климата для данного вида становится рост снежного покрова, «гумидизация» тундр - зимние оттепели и повышение летних температур, которые могут в будущем вновь привести к вымиранию вида в местах современной реинтродукции.

Kопытный лемминг (Dicrostonyx torquatus) - типичный представитель плейстоценовой фауны мелких млекопитающих, имеющих специальные морфологические и поведенческие адаптации к обитанию в экстремально холодном климате. Ареал лемминга в период максимума последнего оледенения в целом совпадет с ареалом овцебыка (рис. 3). Он сохранял свои очертания в Европе вплоть до голоцена. Места обитания вида были приурочены к горным районам. Но уже к среднему голоцену копытный лемминг здесь вымирает, а на Урале сохраняется вплоть до климатического оптимума - атлантическое время. В границах современного ареала (Полярный Урал, Ямал) возраст ископаемых остатков лемминга ограничен концом плейстоцена (поздний дриас) и суббореалом и субатлантическим временем голоцена - от 13 до 1,4 тыс. лет назад. История формирования азиатской части ареала копытного лемминга остается неизвестной. Можно лишь предполагать, что он сформировался примерно в то же время, не позднее среднего голоцена. Среднегодовая температура воздуха в его ареале составляет примерно от $+1^{\circ} \mathrm{C}$ на западной границе (полуостров Канин), до $-16^{\circ} \mathrm{C}$ (побережье Восточно-Сибирского моря), средняя высота снежного покрова колеблется примерно от 20 до 60 см. Ареал ограничен среднегодовыми температурами ниже $0^{\circ} \mathrm{C}$ и высотой снежного покрова, создающей условия для зимних гнезд. Повышение температуры в Арктике будет способствовать сокращению ареала, прежде всего его западной части.

Песец (Vulpes lagopus) - характерный представить арктической фауны с циркумполярным ареалом и с высокой экологической пластичностью. Широкий спектр питания обеспечивает выживание вида в разных частях региона. Он заселяет не только тундру, но и зону лесотундры.

В плейстоцене его ареал охватывал всю северную Евразию (рис. 4). Наиболее южные места обитания в период максимума валдайского оледенения располагались на Пиренеях, в Крыму, на юге Сибири. В период после оледенения ареал медленно сокращался до среднего голоцена. Однако в Западной Европе отдельные популяции в горах сохранялись до суббореала голоцена, а на Урале - 2,1-1,9 тыс. лет назад (субатлантическое время).

В целом палеонтологические данные свидетельствуют, что современный ареал песца в Голарктике начал формироваться с конца плейстоцена (поздний дриас), а окончательно оформился в конце среднего голоцена. Помимо требований к климату среди условий, регламентирующих распространение на юг, присутствует жесткая конкуренция с лисицей (Vulpes vulpes), которая выигрывает соперничество за пищу и вытесняет его.

Последствия потепления для песца будут выражаться косвенно, через изменение кормовой базы. В связи с высокой экологической пластичностью вида эти изменения не окажут влияния на структуру ареала. Потепление может стать благоприятным фактором для увеличения плотности в зоне тундр основного конкурента - обыкновенной лисицы. Это может привести к локальному смещению южной границы на север и деградации популяций, обитающих на Кольском полуострове и в Скандинавии.

Состояние популяций типичных арктических млекопитающих северной Евразии в значительной степени определяется последствиями синергизма действия потепления климата и антропогенных факторов, а не только изменениями среды из-за изменений климата. Наиболее существенными факторами современного распространения арктических видов и динамики их численности выступает рост продуктивности тундр («позеленение» Арктики [5-7]), в процессе которого меняется спектр кормов млекопитающих и спектр их хищников. Существенным фактором изменений климата в XXI в. становится расселение на Север южных видов, например лисицы, которая способна за счет конкуренции вытеснять такой типичный арктический вид, как песец. Для всех без исключения рассмотренных видов критическим фактором может стать рост количества осадков зимой и высота снежного покрова. В данном случае требуется сопряженный мониторинг численности видов арктических млекопитающих в разных частях ареала и динамики высоты снежного покрова в местах их зимней концентрации.

Современные тенденции динамики численности и расширения ареала белощекой казарки в российской Арктике. Примером современной позитивной динамики ареала арктического вида птиц может служить белощекая казарка (Branta 

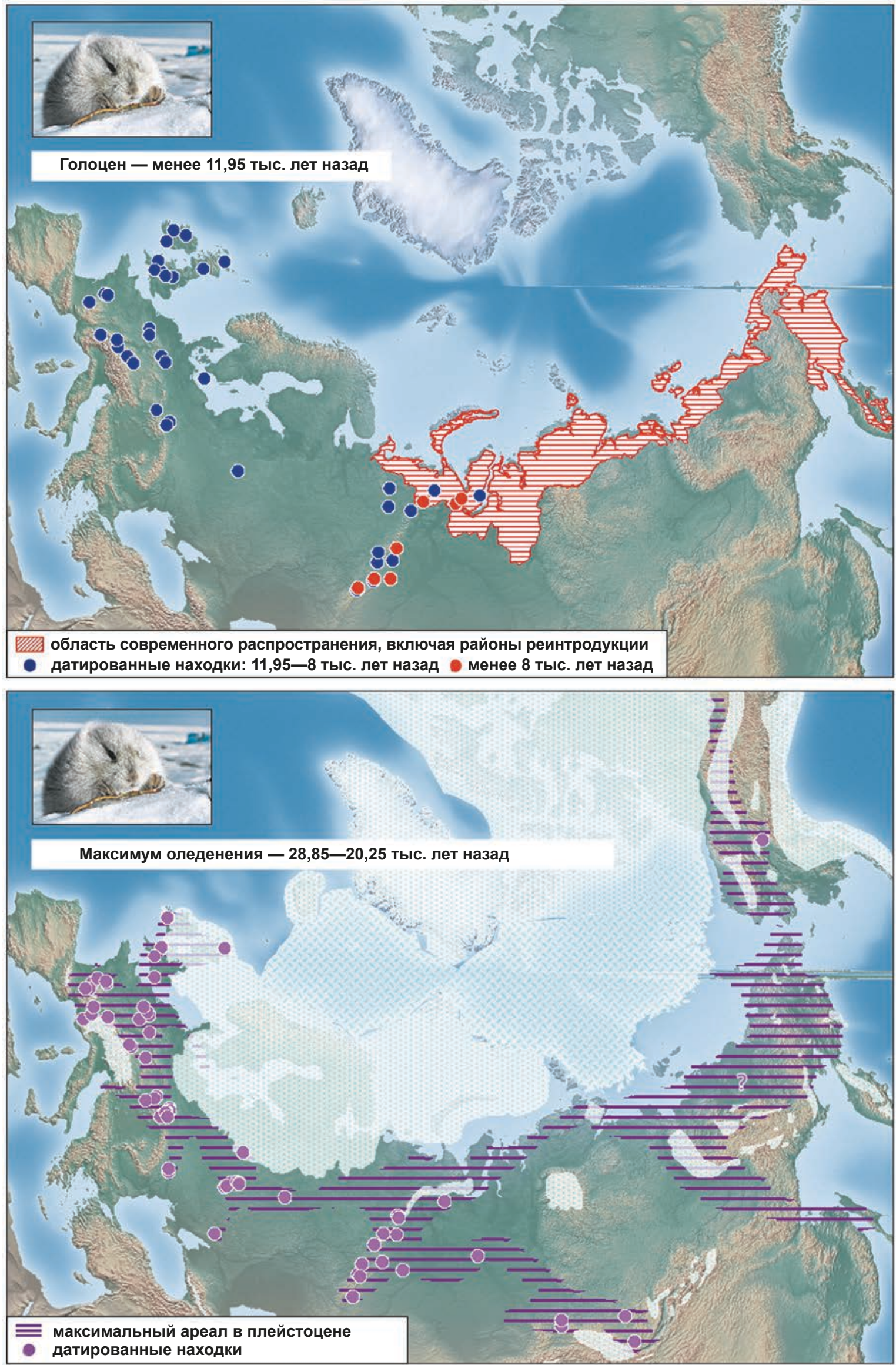

Рис. 3. Ареал копытного лемминга в плейстоцене и голоцене Fig. 3. Arctic Lemming distribution in Pleistocene and Holocene 

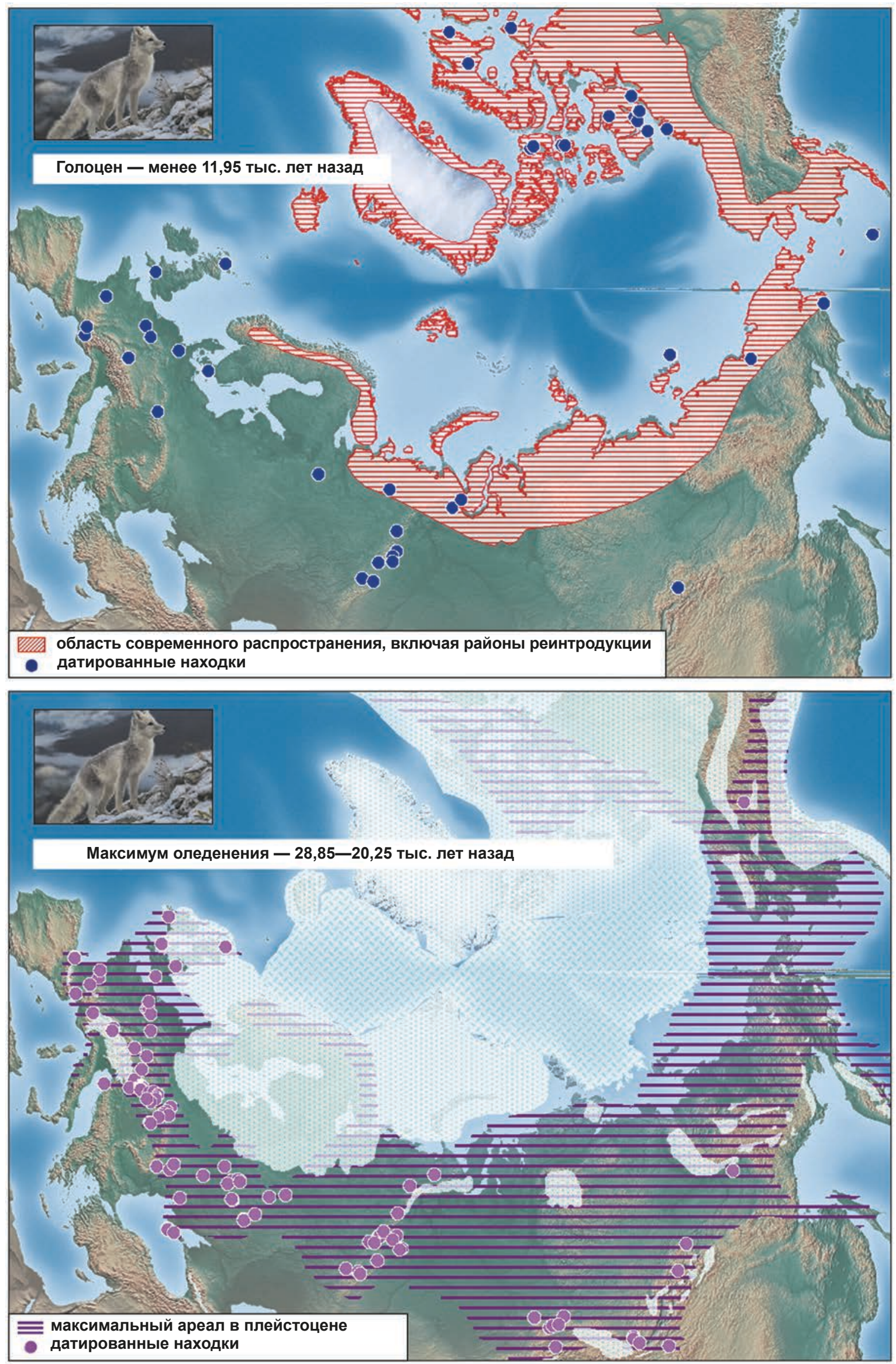

Рис. 4. Ареал песца в плейстоцене и голоцене

Fig. 4. Arctic Fox distribution in the Pleistocene and Holocene 


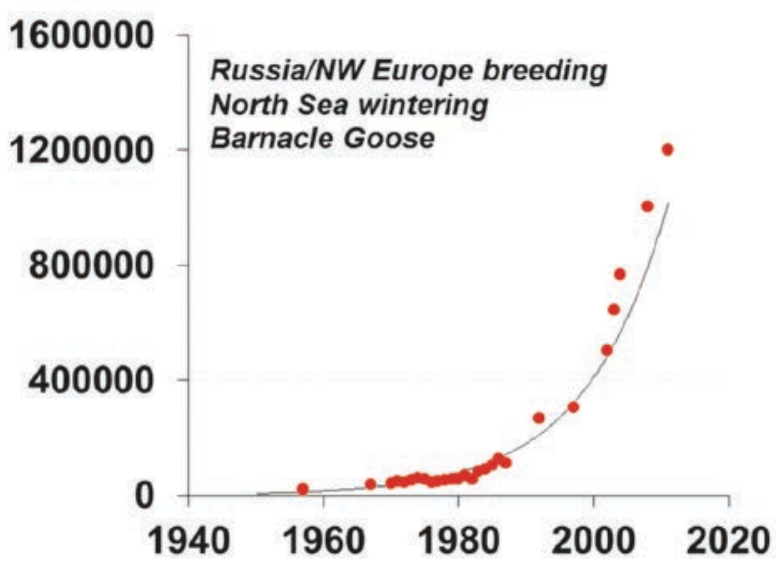

Рис. 5. Динамика численности русско-балтийской популяции белощекой казарки по учетам на зимовках в Европе [18] Fig. 5. Dynamics of the Russian-Baltic population number for Barnacle Goose on wintering counts in Europe [18]

leucopsis) - вид арктических гусей, три изолированные популяции которого гнездятся в российской Арктике, на Шпицбергене и в Гренландии. В середине $X X$ в. численность российской популяции оценивалась в 10 тыс. особей, а гнездовой ареал ограничивался островом Вайгач и архипелагом Новая Земля [10]. Вид даже был включен в «Красную книгу СССР» [11]. Типичными гнездовыми биотопами были скалистые морские острова, кромки морских обрывов и речных каньонов, выступы на скалистых обрывах и останцах [12; 13]. Гнезда могли располагаться под защитой других гнездящихся птиц бургомистров (Larus hyperboreus) и зимняков (Buteo lagopus) [14]. Использование местообитаний, малодоступных для хищников - песца (Alopex lagopus), ограничивало площадь, пригодную для гнездования, и обуславливало мозаичность колоний и отдельных гнезд казарок. Успех гнездования казарок изменялся в широких пределах в зависимости от численности и активности песцов [12; 15].

С конца 1980-х годов начался активный рост численности популяции, сопровождающийся появлением новых колоний на путях миграции вида. Крупнейшие колонии сформировались на полуострове Канин и острове Колгуев [16], более мелкие - на острове Сенгейском, в Колоколковой губе, полуострове Русский Заворот, мысе Медынский Заворот, острове Долгом. Также колонии возникли за пределами Арктики - на островах Балтийского моря. В настоящее время отмечены уже не единичные случаи гнездования вида вне основного ареала и пролетного пути вида на востоке полуострова Таймыр. Параллельно отмечался рост численности вида и расширение его ареала (рис. 5 и 6).

В настоящее время белощекая казарка - один из наиболее благополучных видов гусеобразных северной Евразии. По данным учета на местах зимовок в Европе в 1997 г. численность российской популяции этого вида составляла уже 267000 особей [17], а к 2015 г. - 1200000 особей [18].

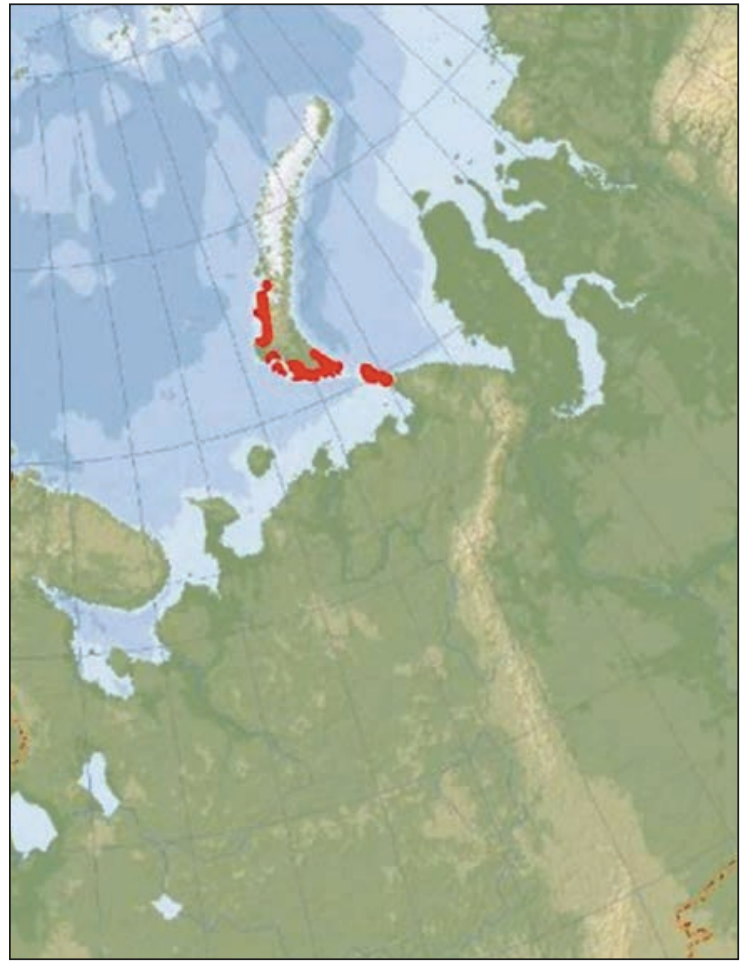

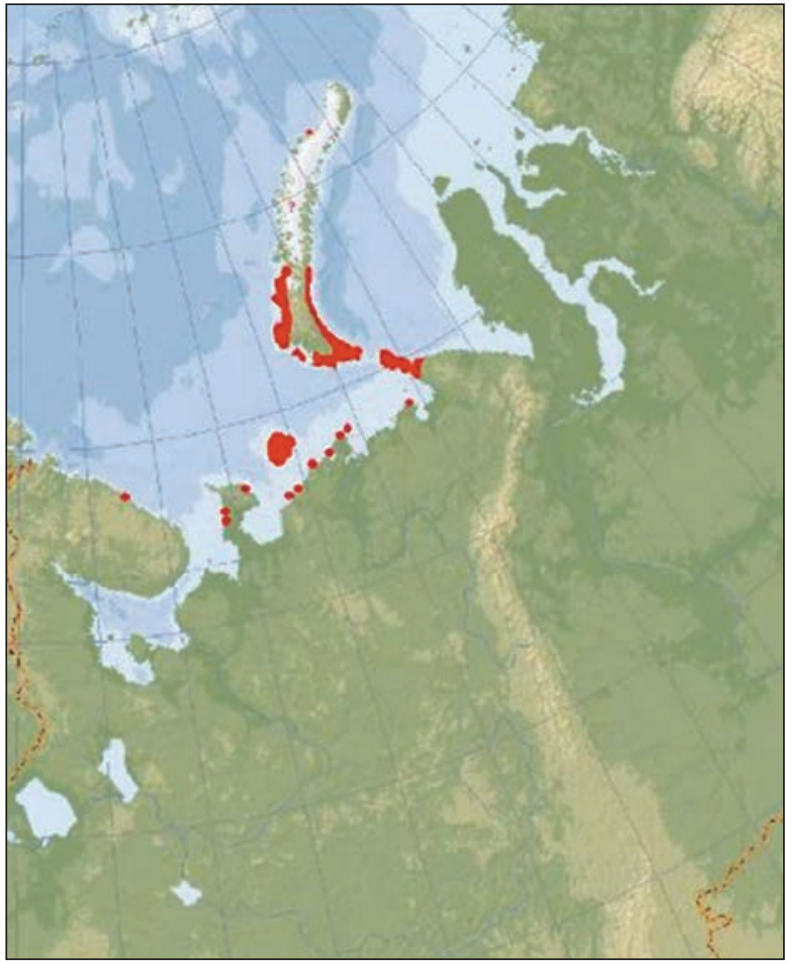

6

Рис. 6. Изменения гнездового ареала белощекой казарки (красный цвет) в российской Арктике: $a$ - до 1950-х годов, 6 современное состояние (2018 г.)

Fig. 6. Changes in the Barnacle Goose nesting range (red) in the Russian Arctic: $a$ - until the 1950s, $\sigma$ - the current state (2018) 


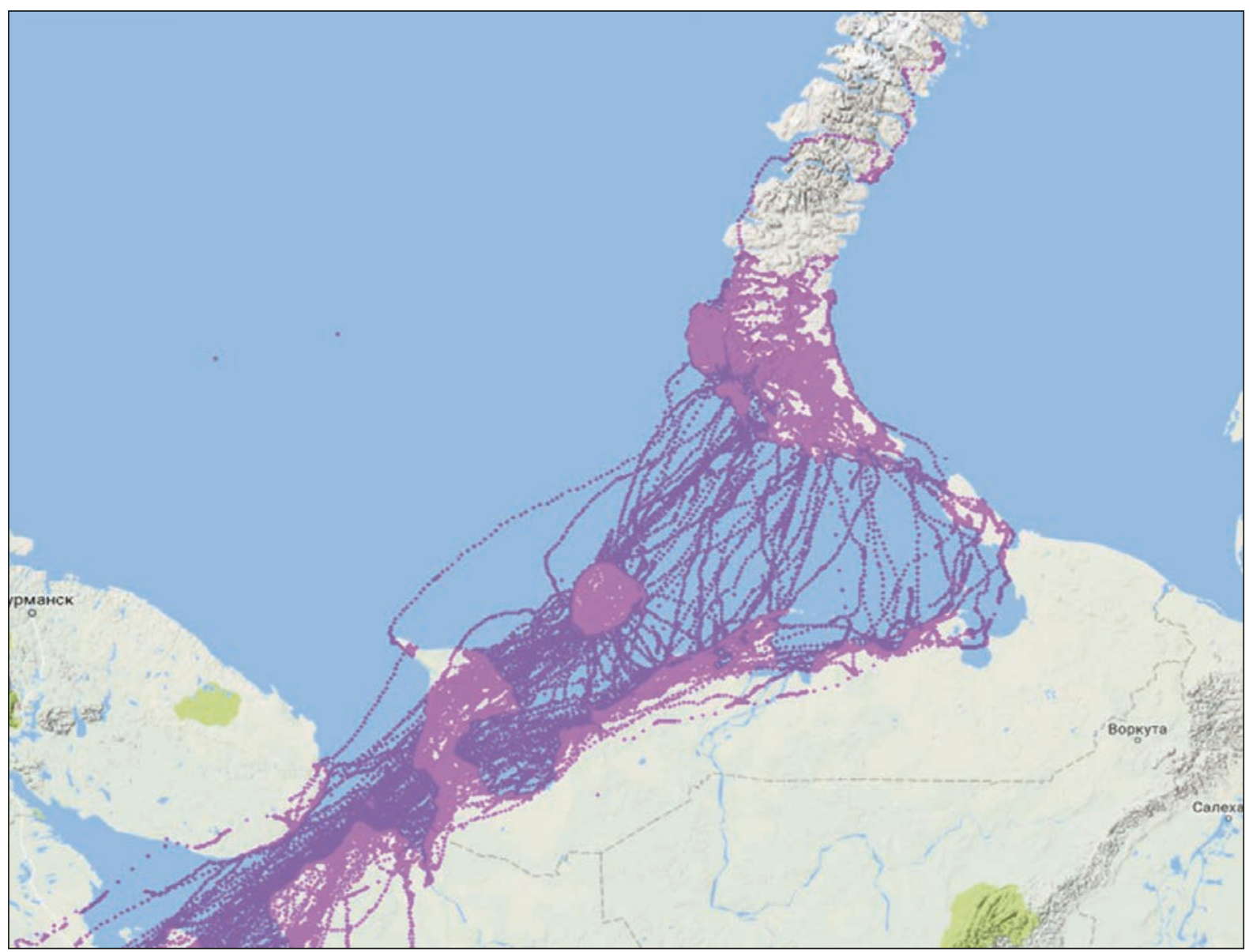

Рис. 7. Треки перемещения белощеких казарок, помеченных GPS-GSM передатчиками на зимовках в Западной Европе и на острове Колгуев (данные П. М. Глазова)

Fig. 7. Movement tracks of Barnacle Geese marked with GPS-GSM transmitters during wintering in Western Europe and on Kolguev Island (data of P. M. Glazov)

В отличие от острова Вайгач и архипелага Новая Земля, где казарки традиционно гнездились на речных и морских скалистых обрывах и мелких прибрежных островах, типичными гнездовыми местообитаниями новых колоний стали приморские марши и песчаные дюны (остров Колгуев, Колоколкова губа). Наблюдения за мечеными особями показали, что птицы в течение жизни могут кардинально менять гнездовые биотопы, выбирая места с разными микрорельефом, укрытостью гнезда, удалением от водоема и кормовыми условиями. Тенденции к освоению новых местообитаний затронули и некоторые традиционные районы гнездования вида (остров Вайгач).

По современным оценкам гнездовая численность белощекой казарки на острове Колгуев составляет не менее 70-80 тыс. пар, на острове Вайгач - не менее 9 тыс. пар, полуострове Канин - не менее 10 тыс. пар. Численность белощекой казарки на колониях побережий Малоземельской и Большеземельской тундры составляет от нескольких сотен до нескольких тысяч особей. Всего численность гнездящихся в Ненецком автономном округе казарок составляет 200-210 тыс. особей. С учетом неразмножающихся птиц (до 25-30\% популяции) и птенцов осенняя численность казарок может достигать 500-600 тыс. особей. При общей численности популяции (по оценкам на местах зимовок) более 1000 тыс. особей можно полагать, что крупнейшие поселения белощекой казарки расположены на островах Новая Земля. $\mathrm{K}$ сожалению, современных данных по гнездованию здесь практически нет, но последние данные спутникового мечения подтверждают это предположение (рис. 7).

На острове Колгуев новые колонии казарки образовались на заболоченных участках тундры (центральная часть острова), где она вступает в конкуренцию за гнездовые местообитания с белолобым гусем и гуменником. В настоящее время она освоила здесь все местообитания и стала гнездиться даже отдельными парами, что не характерно для данного вида.

C помощью датчиков GPS-GSM, повешенных совместно с немецкими коллегами на казарок на зимовках в Европе и на местах гнездования на острове Колгуев, удалось проследить основной миграцион- 


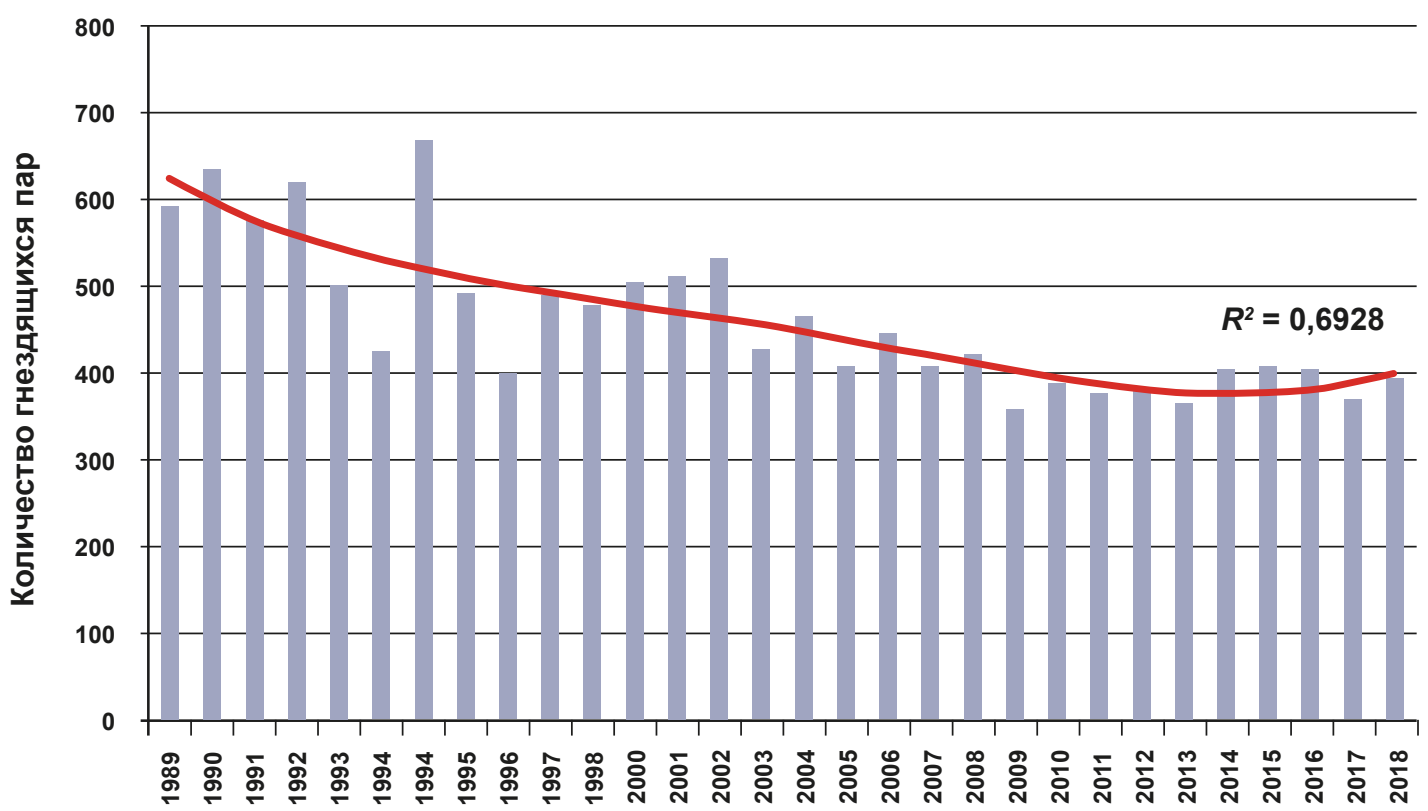

Рис. 8. Динамика численности серебристой чайки на Соловецком архипелаге Белого моря Fig. 8. Herring Gull population dynamics on the White Sea Solovetsky archipelago

ный путь птиц, зимующих в Западной Европе и мигрирующих к местам гнездования Беломоро-Балтийским пролетным путем (см. рис. 7). В последние годы в связи с расширением гнездового ареала наблюдается и расширение миграционного коридора вида. Все больше птиц отмечается на весеннем пролете в средней и южной частях Восточно-Европейской равнины. Основные места гнездования казарок находятся на островах Колгуев, Вайгач и Новая Земля. Многие неразмножающиеся птицы улетают на линьку на Южный остров Новой Земли. Осенняя миграция с мест гнездования к местам зимовок проходит по тому же пролетному пути, но с меньшим количеством остановок на пролете.

Рассмотренный на примере 60-летней динамики популяции казарки цикл роста численности и расширения ареала арктического вида показывает, что не все проявления изменений арктической биоты связаны с изменениями климата. В данном случае, по-видимому, главным фактором благополучия популяции стала охрана зимовок вида в Европе, а только потом, возможно, потепление Арктики, увеличение вегетационного периода и рост продуктивности тундр. Аналогичные изменения прослеживаются и у других видов водоплавающих птиц, но первопричины их могут различаться.

Тренды численности популяций морских птиц в европейской Арктике. Популяции многих видов морских птиц, населяющих арктические и субарктические районы европейской России, демонстрируют в последние десятилетия негативные тренды численности. Именно антропогенными и климатическими изменениями пытались объяс- нить их популяционные тренды и динамику ареалов, в то время как наиболее продолжительная часть жизни, связанная с миграциями и зимовками, была изучена хуже.

Проведенные исследования были направлены как раз на выявление: (1) ключевых районов жизни популяций в период миграций и зимовок, (2) природно-климатических и антропогенных факторов, представляющих наибольший риск для популяций, (3) климатических и экологических условий внегнездовых местообитаний популяций морских птиц и их влияния на динамику численности и границы ареалов, (4) ответной реакции популяций на климатические изменения и связанные с ними процессы.

В качестве модельного вида выбрана серебристая чайка (Larus argentatus) - всеядный вид, добывающий корм с поверхности воды и в береговой зоне суши, в том числе и в антропогенных местообитаниях. Исследования проводили на Белом море в четырех колониях, расположенных на островах Соловецкого архипелага. Распределение серебристых чаек на зимовках изучали путем индивидуального мечения цветными кольцами с индексом и использования GLS-логгеров. За последние 30 лет наблюдается некоторое снижение численности серебристой чайки на Белом море (рис. 8). На Соловецком архипелаге наиболее интенсивно этот процесс происходил с 1990 по 2009 гг. В последующие годы численность стабилизировалась.

Анализ данных, записанных логгерами, и информации о визуальных регистрациях птиц показали, что из 29 меченых серебристых чаек 1 птица зимует в Италии, 2 - в Дании, 8 - в Голландии и по 


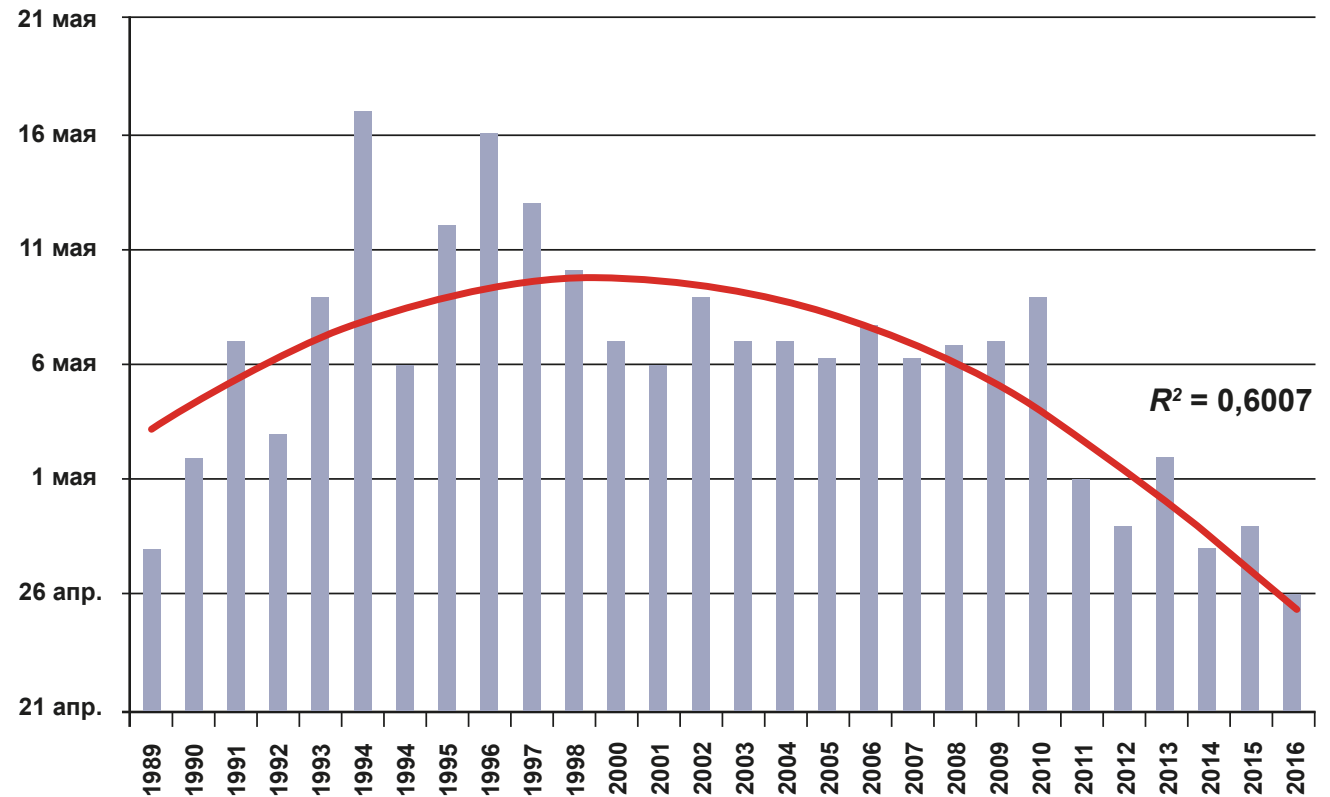

Рис. 9. Начало гнездования серебристой чайки на Соловецком архипелаге Fig. 9. The beginning of Herring Gull nesting on the Solovetsky archipelago

9 чаек - в Германии и Польше. Почти все птицы проводят зиму на побережьях Балтийского и Северного морей. Чайки из одной колонии зимуют в разных районах, и в то же время птицы из разных колоний могут зимовать в одном районе. Места зимовок стабильны, т. е. птица ежегодно прилетает в один и тот же район. Такое распределение чаек на зимовках может быть адаптацией для снижения риска при возникновении неблагоприятных или катастрофических условий в одном из районов. В этом случае пострадает только часть популяции.

Сравнение наших данных с исследованиями 1960-х годов показывает, что 50 лет назад зимний ареал основной части беломорской популяции серебристых чаек включал только самую западную часть Балтийского моря и простирался дальше на юго-запад до устья реки Жиронды [19]. Основным районом зимовки была Дания и примыкающие к ней регионы Германии и Швеции. В настоящее время зимовки сместились на восток, значительная часть популяции не летит дальше балтийского побережья Польши. Миграционный путь стал короче, сократилась и продолжительность зимовки. За последние 30 лет изменилось время прилета серебристых чаек на места гнездования. Но, как показали наши исследования, данные GLS-логгеров и визуальные наблюдения не отражают реальные сроки прилета птиц: многие из них перед началом гнездования пролетают дальше на восток и северо-восток и какое-то время проводят за 200 и более километров от колонии, а район зимовок птицы покидают еще раньше. С 2000-х годов на более ранние сроки сдвинулось и время начала гнездования (рис. 9).
Все ли изменения последних десятилетий в численности, размещении и миграциях серебристой чайки на Соловецком архипелаге можно объяснить изменениями климата? Так, в последние годы наблюдается синантропизация популяций серебристой чайки. Все больше птиц гнездятся в населенных пунктах, в том числе в крупных городах, и добывают корм на помойках и полигонах твердых бытовых отходов. Во время зимовок значительная часть популяции также держится в населенных пунктах. Можно предположить, что негативный тренд численности популяции серебристой чайки связан с трендом максимальной утилизации бытовых отходов в странах Западной Европы. В то же время климатические изменения позволили сдвинуть область зимовок на восток и компенсировать дефицит корма. Кроме того, увеличились время пребывания птиц вне зимовки и возможности поиска корма в других районах.

Некоторые закономерности современной динамики флоры и растительности российской Арктики. Исследования многолетних изменений флоры Арктики пока малочисленны [20]. Из 240 локальных флор, известных для российской Арктики, повторные изучения видового состава проводились лишь в 10 пунктах (около 4\%), расположенных в сибирском секторе. Выводы об изменении видового состава сделать трудно, поскольку статистически они не подтверждаются из-за небольшого их числа. Временной диапазон в 10 обследованных локальных флорах — от 20 до 70 лет, в основном 3040 лет. За этот период в 3 флорах не обнаружено изменений видового состава, в 7 число видов увели- 
чилось, и в большинстве случаев эти изменения произошли из-за увеличения числа (и доли) бореальных и гипоарктических видов на 3-7\%. В бухте Тикси отмечено исчезновение нескольких видов снежников, что может быть связано с более быстрым сходом снега и «усилением присутствия» видов многолетних трав и кустарничков. Основные изменения произошли в локальных флорах лесотундры и близ южной границы тундровой зоны за счет миграции бореальных видов, которые имеют пульсирующую границу ареала.

Все встречи новых видов представляют собой единичные находки, которые никоим образом не могли сказаться на таком явлении, как «позеленение» Арктики, которое отмечается в последнее время [5-7; 21-24]. Отмечаемые изменения NDVI могут быть связаны с увеличением обилия и встречаемости ив и других кустарников в результате их экспансии из долинных местообитаний в прилегающие водораздельные пространства.

Нельзя сказать, что наблюдаемые заносы «новых» для флор видов растений являются «инвазиями», т. е. появлением их в результате антропогенной деятельности. В зафиксированных изменениях состава локальных флор число видов, занесенных человеком, минимально и отмечено не в каждом случае [20]. Например, при повторном обследовании флоры окрестностей поселка Хатанга (Таймырский заповедник) обнаружено всего 4 вида, которые можно отнести к чужеродным [25; 26]: Chenopodium suecicum, Stellaria media, Raphanus raphanistrum, Plantago major, находки их единичны, и эти виды являются случайными по инвазионному статусу, а рудеральные местообитания здесь заселяются аборигенными видами. Остальные изменения состава данной локальной флоры (более 80 видов!) связаны с миграциями бореальных видов, которые могли иметь место в результате изменения локальных (местных) климатических условий.

Инвазии сосудистых растений в российской Арктике пока редки. Инвазионный статус вида, или степень натурализации, - характеристика региональная, и инвазионным вид считается для достаточно крупного региона. Для Мурманской области, Ненецкого, Ямало-Ненецкого и Чукотского автономных округов они единичны. Однако чужеродные виды и даже натурализовавшиеся есть, они приурочены к: (а) достаточно крупным населенным пунктам, где могут быть несколько «смягченные» климатические условия и нарушенные местообитания, (б) местам культивирования видов, (в) морским побережьям. Так, в Мурманской области борщевик Сосновского Heracléum sosnówskyi отмечен в окрестностях Полярно-альпийского ботанического сада-института (где выращивался с коллекционными целями). Там же найдены Sorbaria sorbifolia, Impatiens glandulifera и некоторые другие вредоносные чужеродные виды, которые достаточно широко расселились в умеренных областях европейской части России. На побере- жье Белого моря в районе мыса Корабль найдена Rosa rugosa, в настоящее время распространившаяся по побережьям Балтийского, Норвежского и Северного морей. В течение последнего десятилетия в крупных городах Ямало-Ненецкого автономного округа отмечено значительное число заносных видов, которые ранее во флоре округа не отмечались: в Надыме - около 45 видов, в Ноябрьске - 80, из них около половины бореальные, большинство не натурализуется, но возрастание числа новых видов характеризует рост антропогенного давления.

Изменения во флоре арктических областей не являются ни причиной, ни следствием «позеленения» Арктики - наблюдаемых изменений в продуктивности. В настоящее время отмечается небольшое увеличение доли бореальных и гипоарктических видов во флорах лесотундры и юга тундровой зоны, что может быть связано с изменением локального (или регионального) климата и миграцией видов в результате увеличения частоты пульсации видовых ареалов близ их границы. Однако все встречи единичны и не сказываются на структуре растительных сообществ. «Позеленение» (в том числе изменения NDVI) непосредственно объясняется: (а) увеличением обилия, проективного покрытия и частоты встречаемости кустарников, (б) увеличением общей фитомассы, что отмечено, например, при исследовании растительности островов Вайгач и Колгуев [27]: тенденция нарастания зеленой фитомассы (с 1986 по 2011 гг.) прослеживается в разных типах растительных сообществ и связана с общим увеличением продолжительности вегетационного периода и ростом летних температур.

Изменения структуры растительного покрова могут варьировать и по регионам. Так, для подтверждения гипотезы о механизмах «позеленения» в Арктике был проведен анализ динамики границы леса в модельных районах Кольского полуострова. Использованы данные Global Land Analysis \& Discovery group Университета Мэриленда (США) ${ }^{1}$ о лесном покрове (tree cover) за 2000 и 2010 гг., полученные на основе анализа данных снимков среднего разрешения со спутников серии Landsat (рис. 10).

Видно, что существует очевидный тренд к увеличению лесопокрытой площади и/или сомкнутости лесов. По-видимому, на всей этой территории он связан с увеличением средних температур и осадков в регионе. Особенно заметные изменения в площадях древесной и кустарниковой растительности произошли на территориях: (1) к югу от поселков Никель и Заполярный, где расположены металлургические комбинаты АО «Норильский никель» (это связано и с восстановлением лесов, раннее поврежденных выбросами комбинатов), (2) вдоль гряды Кейвы, а суммарно на 773379 га - увеличение лесистости более чем на 15\% в пикселе, и только на 16233 га - уменьшение более чем на 15\%. По-

\footnotetext{
${ }^{1}$ https://glad.umd.edu/.
} 


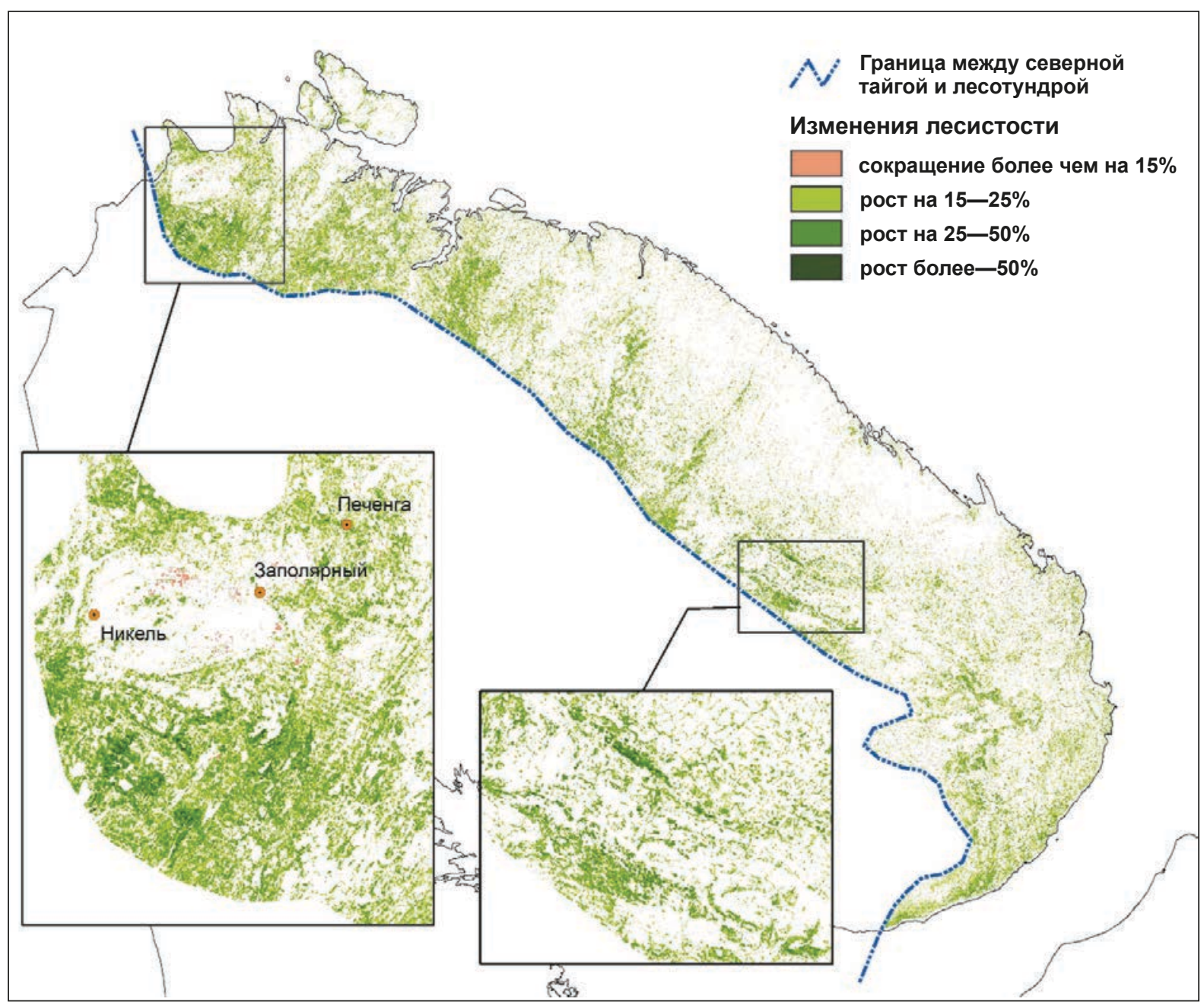

Рис. 10. Увеличение лесопокрытой площади в период с 2000 по 2010 гг.) в зонах тундры и лесотундры Мурманской области Fig. 10. The forest area increase within the period 2000-2010 in the tundra and forest-tundra zones of the Murmansk region

следнее в основном связано с пожарной динамикой лесной территории.

Для полуострова Таймыр выделяются разнонаправленные процессы [25; 26; 28; 29]. Выявлено, что состав и структура растительных сообществ арктических областей остаются, как правило, без коренных изменений. Незначительно меняется только площадь некоторых местообитаний, что связано с направленным изменением гидрологического режима территории. Так, наиболее выражены изменения растительности во влажных экотопах - в зоне влияния снежников, на болотах и в мелководных водоемах.

В заключение отметим, что интенсивность полевых исследований в Арктике в последние десятилетия снизилась, что не позволяет дать более детальный анализ и синтез перестроек в арктической биоте, спровоцированных «биотически значимыми» изменениями климата.

Работа выполнена по гранту РФФИ № 18-0560057 «Позеленение» тундры как драйвер совре- менной динамики арктической биоты» и в рамках госзадания № 0148-2019-0007 Института географии РАН «Оценка физико-географических, гидрологических и биотических изменений окружающей среды для создания основ устойчивого природопользования».

\section{Литература}

1. Кокорин А. О. Изменение климата: обзор Пятого оценочного доклада МГЭИК. - М.: Всемир. фонд дикой природы (WWF), 2014. - 80 с.

2. Второй оценочный доклад Росгидромета об изменениях климата и их последствиях на территории Российской Федерации: Техническое резюме. - М.: Росгидромет, 2014. - 94 с.

3. Serebryanny L. R., Tishkov A. A., Malyasova Je. S. et al. Reconstruction of the development of vegetation in Arctic high latitudes // Polar Geography and Geology. 1985. - Vol. 9, № 4. - P. 308-320.

4. Тишков А. А. Экосистемы западного побережья Шпицбергена (архипелаг Свальбард) // Изв. АН СССР. Сер. геогр. - 1983. - № 6. - С. 99-109. 
5. Тишков А. А., Кренке-мл. А. Н. «Позеленение» Арктики в XXI в. как эффект синергизма действия глобального потепления и хозяйственного освоения // Арктика: экология и экономика. - 2015. - № 4 (20). - C. 28-37.

6. Белоновская Е. А., Тишков А. А., Вайсфельд М. А. и Әр. «Позеленение» российской Арктики и современные тренды изменения ее биоты // Известия РАН. Cер. геогр. - 2016. - № 3. - C. 28-39. - DOI: 10.15356/0373-2444-2016-3-28-39.

7. Тишков А. А., Белоновская Е. А., Вайсфельд М. А. и др. «Позеленение» тундры как драйвер современной динамики арктической биоты // Арктика: экология и экономика. - 2018. - № 2 (30). - С. 31-44. DOI: 10.25283/2223-4594-2018-2-31-44.

8. Маркова А. К., ван Кольфсхотен Т., Бохнкке Ш. и др. Эволюция экосистем Европы при переходе от плейстоцена к голоцену (24-8 тыс. л. н.). - М.: Изд-во KMK, 2008. - 556 c.

9. Olson D. M., Dinerstein E., Wikramanayake E. D. et al. Terrestrial ecoregions of the World: A New Map of Life on Earth // Bioscience. - 2001. - Vol. 51, № 11. - P. 933-938.

10. Успенский С. М. Некоторые виды птиц на северо-востоке европейской части СССР // Уч. зап. Моск. ун-та. - 1958. - № 197. - С. 35-47.

11. Красная книга СССР: Редкие и находящиеся под угрозой исчезновения виды животных и растений. Т. 1. - 2-е изд. - М.: Лесная пром-сть, 1984. - 392 с. 12. Калякин В. Н. Новые данные по фауне птиц Новой Земли и Земли Франца-Иосифа // Орнитология. - 2001. - № 29. - С. 8-28.

13. Морозов В. В. Материалы к познанию фауны птиц острова Вайгач // Орнитология. - 2001. - № 29. С. 29-46.

14. Калякин В. Н. О распространении и экологии белощекой казарки на о-ве Вайгач и Югорском полуострове // Актуальные проблемы орнитологии. - М.: Наука, 1986. - С. 93-104.

15. Syroechkovsky E. V., Litvin K. E., Ebbinge B. S. Breeding success of geese and swans on Vaygach Island (USSR) during 1986-1988; interplay of weather and Arctic Fox predation // Ardea. - 1991. - Vol. 79 (3). - P. 373-382.

16. Пономарева Т. С. Белощекая казарка. Новое гнездовое поселение в окрестностях о. Колгуева // Итоги изучения редких животных (Материалы к Красной книге). - М.: ЦНИИЛ Главохоты РСФСР, 1990. - C. 81-84.

17. Ganter B., Larsson K., Syroechkovsky E. V. et al. Barnacle Goose Branta leucopsis: Russia/Baltic // Goose populations of the Western Palearctic. A Review of Status and Distribution / J. Madsen, G. Cracknell, T. Fox (eds.). - Wageningen, 1999. - P. 270-283.

18. Fox A. D., Madsen J. Threatened species to superabundance: The unexpected international implications of successful goose conservation // Ambio. - 2017. -
Vol. 46 (Suppl. 2). - P. 179-187. - DOI 10.1007/ s13280-016-0878-2.

19. Бианки В. В. Кулики, чайки и чистиковые Кандалакшского залива // Тр. Кандалакш. гос. заповедника. - 1967. - Вып. 6. - 365 с.

20. Khitun O. V., Koroleva T. M., Chinenko S. V. et al. Applications of local floras for floristic subdivision and monitoring vascular plant diversity in the Russian Arctic // Arctic Science. - 2016. - Vol. 2. - P. 103126. - DOI: 10.1139/AS-2015-0010.

21. Myers-Smith I., Forbes B. C., Wilmking M. et al. Shrub expansion in tundra ecosystems: dynamics, impacts and research priorities // Environ. Res. Lett. - 2011. Vol. 6 (4). - 045509.

22. Elmendorf S. C., Henry G. H. R., Hollister R. D. et al. Global assessment of experimental climate warming on tundra vegetation: heterogeneity over space and time // Ecology Letters. - 2012. - Vol. 15 (2). - P. 164175. - DOI: 10.1111/j.1461-0248.2011.01716.x.

23. Walker D. A., Epstein H. E., Raynolds M. K. et al. Environment, vegetation and greenness (NDVI) along the North America and Eurasia Arctic transects // Environ. Res. Lett. - 2012. - Vol. 7 (1). - 015504. - DOI: 10.1088/1748-9326/7/1/015504.

24. Callaghan T. V., Jonasson C., Thierfelder T. et al. Ecosystem change and stability over multiple decades in the Swedish subarctic: complex processes and multiple drivers // Philosophical Transactions of the Royal Society B. Biological Sciences. - 2013. - Vol. 368 (1624). — DOI: 10.1098/rstb.2012.0488.

25. Поспелова Е. Б., Поспелов И. Н. Изменения во флоре окрестностей с. Хатанга, Таймырский заповедник, за длительный период // Заповед. наука. 2016. - T. 1 (2). - С. 59-78.

26. Поспелова Е. Б., Поспелов И. Н., Орлов М. В. Воздействие климатических колебаний на востоке Таймыра за 80-летний период на растительный и животный мир его территории // Науч. тр. Федер. гос. бюджет. учреждения Объединенная дирекция заповедников Таймыра. - Т. 2. - Апекс; Норильск, 2018. - С. 127-141.

27. Лавриненко И. А., Лавриненко О. В. Влияние климатических изменений на растительный покров островов Баренцева моря // Тр. Карел. науч. центра. - 2013. - № 6. - С. 4-16.

28. Матвеева Н. В., Заноха Л. Л., Янченко З. А. Изменения во флоре сосудистых растений в районе Таймырского биогеоценологического стационара (среднее течение реки Пясины, Западный Таймыр) с 1970 по 2010 г. // Ботан. журн. - 2014. - Т. 99, № $8 .-$ C. $841-867$.

29. Pospelova E. V., Pospelov I. N., Orlov M. V. Climate change in Eastern Taimyr over the last 80 years and warming impact on biodiversity and ecosystem processes in its territory // Nature Conservation Research. - 2017. - Vol. 2 (3). - P. 48-60. - DOI: 10.24189/ncr.2017.040. 